\title{
Visa Policies and Visa Openness Scores in SADC - An Exclusion Element of Tourism Development in Southern Africa: A Critical Interjection
}

Erisher Woyo*

\begin{abstract}
The objective of this paper is to critically show how visa policies in Southern Africa affect tourism development. The paper adopted a regional perspective on the dynamics of visa policies affect tourist flows. This article also discusses the implications of visa policies on tourist arrivals. Government efforts in influencing the change in visa policies are also discussed in this paper. The study identified three main reasons why visa policies are pursued; namely, border security; minimising illegal immigration and reciprocity. The paper concludes that, while visa policies may help tourist destination within the region with revenue, they have a more deterring effect as it affects destination choice and visa openness scores, thus affecting tourism development.
\end{abstract}

Keywords: visa, visa openness scores, Southern Africa Development community, tourism development

\section{Introduction}

The tourism industry has developed quicker in the last three decades owing to advances in information communication technologies (Buhalis \& Law, 2008; Hays, Page \& Buhalis, 2013; Ayikoru, 2015), growing purchasing power and developments that

* International University of Management, Namibia; e.woyo@ium.edu.na 
continues to shape the global economy at large (Pestana, Laurent, Nicolas, Elisabeth, Bernardin, \& Assaf, 2011). There is no doubt that tourism is now big business and the economic benefits are therefore an important factor for both developing and developed. Economic dimension of the tourism industry is quite real and there is no doubt empirically that it is the largest foreign currency earner with daily revenues of US $\$ 2$ billion (Future Brands, 2006 cited in Balakrishnan, 2009). The total contribution of tourism activities to the world economy in 2013 alone were forecasted at 2.9 percent (WTTC, 2013). Literature that outlines the economic impacts tourism growth in various destination economies is widely confirmed in the wider tourism literature (Song, Dwyer, Li \& Cao, 2012; Webster \& Ivanov, 2015), resulting in a fierce rivalry among tourism destinations (Dwyer, Edwards, Mistilis, Roman, \& Scott 2009; Molina, Frías-Jamilena, \& Castaneda-García, 2013; du Plessis, Saayman, and van der Merwe, 2015). 1.8 billion tourists expected to visit global destinations by the year 2030 (UNWTO, 2003). There is no doubt that, the tourism industry remains the fastest growing service sector in the global economy.

Revenue that is generated from tourism is used by various countries across the globe to sustain government activities and a number of wider national investments. Globally, the industry in 2013 was estimated to be worth US $\$ 1.4$ trillion, with a yearly per cent increase dating back from the year 2009. Therefore, it is imperative to note that, the value of properly managed tourism resources cannot be overemphasised or denied. UNWTO estimates that by 2020, international arrivals are expected to reach 1.6 billion people annually. However, countries in the world use visa policies as a way of monitoring and controlling of border movements and the earliest travel visas were found in the court of French King Louis XIV who during his reign will issue a document that permits a "pass par tout" over international borders for his court favourites (Lieberman \& Lautenberg, 1991), though during that time, they were not seriously enforced until after the second world war when border security again became an important factor for many nations.

National governments across the globe are increasingly investing public resources that include tax dollars in activities and programmes such as nation branding for purposes of developing 
competitive destinations (Anholt, 2005; Kotler \& Gertner, 2002). While tourism growth has been witnessed on the African continent, with du Plessis et al., (2015) suggesting that, $12 \%$ of international tourists visited Africa in 2012, visa policies within the SADC region as a tourism destination continues to inhibit the growth of international tourism (UNWTO, 2015). According to Song, Hong and Tasci (2012), national governments imposes strict visa regulations and this sometimes affect the productivity of branding and marketing efforts carried out using taxpayers' money. Extant literature on the effects of restrictive visa policies on tourism demand and growth in the wider tourism literature is quite scanty in terms of how visa restrictions affect the growth of international tourism across the globe (Song et al., 2012). The concern of this paper is to critically review, interject and discuss the exclusion effects of

Tourism industry is considered one of the fastest and important growth sectors for SADC economies. It has been since time immemorial being creating numerous direct and indirect jobs via the multiplier concept in various economic sectors for the SADC region as a tourism destination. Viviers and Slabbert (2012) note that, the contribution of the tourism industry in terms of sustainable development is well documented and national governments have long accepted tourism as a poverty alleviation tool. According to WTTC (2014), tourism within SADC economies contributed 5\% to Gross Domestic Project in 2013.

The direct contribution of tourism to GDP was US420.6 billion in 2015, and it is projected to increase by $3.1 \%$ in 2015 and to rise by $5.2 \%$ per year from $2015-2025$, to US35.2 billion (3.1\% of total GDP) in 2025 (WTTC, 2015). The total contribution of tourism to GDP was US $\$ 58.2$ billion (8.6\% of GDP) in 2014, and is forecast to rise by $3,2 \%$ in 2015 and to rise by $5 \%$ per year to US497.8 billion $(8.8 \%$ of GDP) in 2025. WTTC (2015) notes that the tourism industry in the SADC region's direct contribution to employment was 2.4 million jobs (3.1\% of total employment).

UNWTO (2015) argues that the visa policy in SADC is among the key inhibiting factors on international tourism directed by various governments. The development of policies and procedures for visas has got a direct link with the development of international tourism 
and its growth. Glaesser and Kester, (2013) argue that, with the growth of international tourism within the last six decades, the quality, reliability and functionality of visa and other travel documents has evolved. Regrettably, the same authors bemoaned the situation in South Africa in terms of opening up its visa regulations and scores only 29/100 in "openness to tourism" scale. It also goes without saying that, of the 15 member states of SADC, none has implemented an e-visa and only a few offer visas upon arrival at the port of entry a sharp contrast of the current situation in East Africa which scored 49/100. East African countries like Kenya, Rwanda and Uganda has got a Univisa which they launched in 2014, thus opening up for more international tourism.

\section{The Rationale of Visa Policies}

There appears to be no universal acceptance among researchers from the limited prose on visa regulations as to what perspectives to follow when approaching the issue. Using a sociological perspective, visa regulations have been described as master/slave relationship in that national governments use them as a way of identifying, differentiating and controlling between citizens and non-citizens (Torpey, 1998). Thus according to this approach, visas are defence mechanisms that have been embraced in modern day "slavery" against the unwanted foreigners in terms of national security and the issue of fear losing economic opportunities that is believed is associated with an influx of foreigners. Another school of thought believes that, visas are good control mechanisms that nations are embracing as they try to deal with the challenges of a globalised and borderless world (Neumayer, 2006).

Visa policies in today's world are created with three primary factors in mind, that is, border security (Bianchi, 2006; UNWTO, 2015), minimising illegal migration (Whyte, 2009; European Commission Directorate -General Home Affairs, 2011; UNWTO, 2015) and reciprocity (Lieberman and Lautenberg, 1991; UNWTO, 2015). Additionally, visa policies serve to ensure that they also limit the entry, duration of stay or activities of travellers; generate revenue and to ensure that a destination's carrying capacity is maintained as well as controlling tourism demand (UNWTO, 2015; Whyte, 2009). While 'border security' seems to the be most 
significant and commonly stated reason behind the imposition of visa requirements, in practice, all functions that are documented in the wider tourism literature form a reason to introduce and maintain visa policies. It is from this perceptive that this paper views visa policies particularly in the SADC region to be an exclusion element that stifles tourism growth, development and competitiveness given that travellers always view visas as a formality that makes the destination to be expensive (Rizzi, 2014; UNWTO, 2015). Cost implications of visa policies are either direct monetary costs imposed in the form of fees or indirect costs which include distance, time spent waiting in very long queues and the complexity of the whole process. These are some of the factors that were noted by Rizzi (2014) as deterrents of tourist movement and as a result, will make tourists to switch destinations favouring those will less hassles.

The reciprocity visa policy explains bilateral relations where on one hand, a country may deny or require full visas for citizens of another country in response to similar polices by another country. For instance, Brazil is one country that pursues the reciprocity visa policy as it charges US\$150 in visa fees and demands biometric information from US citizens mainly because the US has similar policies in place for the Brazilians. The challenge of using reciprocity to inform the design and formulation of visa policies is that it has the tendency to fluctuate when the temperature of international relations changes. Therefore, given the fact that, the tourism industry is volatile to changes in the temperature of international relations, there is need for governments across the SADC region to question how visa policies may affect the visitor as a way of building and encouraging the block's positive return from the tourism industry. Additionally, other critical questions that the SADC member states must think about relate to: How do overly restrictive and time consuming visa policies (inclusive of paper work, fees, processing, giving fewer days than entitled) influence the perception of the tourism destination for legitimate travellers? The author is of the view that, the SADC region will stand to benefit from streamlining its visa facilities through the reduction of paperwork that is required and visa fees as this will help SADC member states to increase tourism numbers and tourism revenue. Additionally, SADC member states must also move with speed in 
relation to visa facilitation through technological advances, visa waivers and a reduced strain on immigration resources. While African Union has recently launched the e-passport to diplomats, more is required on the general traveller. The author is the opinion that, the visa policies and procedures in the SADC region forms an exclusion element in relation to tourism development as this affect traveller destination perception and choice and inherently deters the flow of genuine tourism revenue as a consequence (Douglas, Lubbe, and Kruger, 2012).

According to UNWTO (2013), visa policies and procedures are among the most significant governmental formalities that influences international tourism, particularly destination choice and perception (Douglas et al., 2012; Song et al., 2012; Rizzi, 2014). There is a symbiotic relationship between the development of visa policies and procedures and the development of tourism, to an extent that, poor visa policies has serious ramifications on tourism revenue (Song et al. 2012) and deter tourist movement (Rizzi, 2014). With the swift growth of international tourism in the last six decades, the quality, reliability and functionality of visas and other travel documents has evolved greatly (UNWTO, 2013). While a great deal of progress has been made in terms of visa facilitation, which has contributed towards the remarkable growth of the tourism sector, the story remains different for Southern Africa countries (UNWTO, 2015) as travel to this region is heavily impacted by customs regulations, currency exchange limitations and too rigid visa formalities (UNWTO, 2013).

While other countries like Mozambique and Seychelles have made great progress in terms of visa facilitation, the visa openness index of the SADC region remains critically low and there is no greater exclusion that a low visa openness index. Additionally, it is important that, while SADC member states multilateral agree that visitors from within the SADC region are mutually exempted from visa requirements, the situation on the ground seems to suggest otherwise as the current visa policies seem to be inadequate and inefficient and this could be the reason why visa policies in SADC are hindering tourism growth, development and competitiveness. 


\section{Global and Regional Dimensions to Visas}

During the June 2012 Summit, the G20 leaders recognised the role that tourism plays as a vehicle for job creating, economic growth and development (Glaesser \& Kester, 2013) and this was as a result of the work by both the UNWTO and WTTC. Thus, it is noted that during the 2012 G20 Summit, the leaders committed to work towards the developing travel facilitation initiatives in support for job creation, quality work, poverty reduction and global growth (Glaesser \& Kester, 2013). Nevertheless, in spite of many recent strides taken, visa requirements and procedures still affect global tourism significantly (Rizzi, 2014; Douglas, et al., 2012; Song et al., 2012). In 2012, destinations around the world requested, on average, that 63 percent of the world's population obtain a visa before initiating their international journey (UNWTO, 2013; Glaesser \& Kester, 2013) as shown in Table II below. Another 2 percent of the population were at least allowed to apply for an eVisa, while 16 percent would be able to apply for a visa on arrival. Only 18 percent of the world's population would not require a visa at all when traveling for tourism purposes

Globally, Africa requires a visa prior to departure from $62 \%$ of the world's population, and at the same time, it has the highest percentage of countries whose visitors are able to obtain visa on arrival (28\%) (Glaesser \& Kester, 2013). However, it is imperative to note that, this figure varies significantly across African sub-regions particularly the SADC sub-region. In central Africa, the use of traditional visas - required for $91 \%$ of the world's population is deemed to be the highest of all Africa's sub-regions. In contrast, East Africa has the lowest in the world: only $32 \%$ of the world's population is required to have traditional visas while visa on arrival is popular in East Africa $(60 \%)$, making East Africa together with South East Asia the second most open sub-regions in the world (Glaesser \& Kester, 2013).

\section{SADC Visa Openness Index}

The Africa Visa Openness Index (AVOI) measures how open African countries are in relation to visa. The index is arrived at by looking at what they ask citizens from other countries in Africa when they travel. The aim of AVOI is to show at glance which 
countries are facilitating travel for citizens of other countries and how: whether they allow people to travel to their country without a visa, if travellers can get visa on arrival in the country or if visitors need to get a visa before they travel. AVOI uses data collected from the immigration, visa agencies and travel operators across the African Continent. Additionally, this particular data also include data on visa regulations collected by McKinsey and Company, UNECA and the African Development Bank (AfDB). The AVOI track changes in the country's score over a period of time as a way of assessing and showing which countries are making improvements that support freer movement of people across the African continent.

According to the Africa Development Bank (ADB) (2016) and Glaesser \& Kester, (2013), the higher the score index the country has, the more visa open it is and the higher its ranks among other tourism destinations. It is imperative to note that, each of the above mentioned category is weighted based on the destination's degree of visa openness. Therefore a country's score according to ADB (2016) is computed by summing the results from the index category indicators: $(\%$ of visa required $\times 0)+(5$ of visa on arrival $\times .8)+(\%$ of no visa $\times 1)=$ country visa openness score.

It can be seen from Table IV above that on average Southern Africa is more closed off to each other than open and this makes travel within the SADC difficult and the same is true for the majority of African countries (Africa Development 2016). The ADB (2016) notes that, $55 \%$ of Africans need visas to travel to other African countries while Africans who can get visas on arrival in other African countries amounted to $25 \%$ with only a paltry $20 \%$ of the Africans do not need a visa to travel to other African countries.

A quick global comparison shows that travellers from North America have easier travel access to the greater African continent as well as the SADC region than Africans themselves (ADB, 2016) since North Americans who require visa to travel only amounts to $45 \%$ of African countries; get on arrival in $35 \%$ of African countries and do not need a visa in 20 African countries (McKinsey \& Company, 2015). It is from this perspective where this paper argues that visa policies are drivers of exclusionism in terms of tourism development and growth. The analysis of these findings by ADB 
(2016) and McKinsey and Company (2015) shows that free movement of people is not a reality across Africa in general and the SADC region in particular, hence the argument that visa policies are exclusion elements of tourism development, growth and competitiveness. Seychelles is the only top performing country in Africa and in the SADC in terms of visa openness. Seychelles is a 100 per cent visa free meaning that there are no visa requirements for any person wishing to travel to the country. Africans and all international tourists are not required to have a visa for entry in Seychelles, despite the fact that nationals of Seychelles are required to have a visa for them to visit 34 African countries, which translates to over $60 \%$ of the continent (ADB, 2016).

\section{The Impact of Visa Restrictions on the Tourism Sector Increasing tourism revenue}

Travel visas are dominantly issued through the embassies, high commissions and consulates and the process has been considered to be time-consuming, costly and labour-intensive (Rizzi, 2014:308). Neumayer (2010:19) argues that, the process that is involved in the facilitation of the travel visa is in itself ill-equipped to deal with peaks in demand which is often exacerbated by timings of connection to in-country databases, document verification, visa printing and issuance (Rizzi, 2014:308). Extant literature shows that countries that have already implemented e-visas have benefited from an increased growth of tourism arrivals (Rizzi, 2014:308), quite different scenarios for the SADC member states. The implementation of the US waiver programme accounted for $46 \%$ growth over a three-year period from the Czech Republic, Estonia, Hungary, Latvia, Lithuania, Slovakia and the Republic of Korea. Additionally, Australia saw a 7.9\% growth in its tourism arrivals over the next three years from all countries after the introduction of the Electronic Travel Authority programme. The Indian 'Visa on Arrival" programme has also seen a $10.6 \%$ growth in terms of tourist arrivals from countries such as the New Zealand, Finland, Luxemburg, Japan, Indonesia, the Philippines Singapore, Cambodia, Laos, Myanmar and the Vietnam in the span of one year (WTTC, 2012). 
Within the context of the SADC region, Seychelles has been considered to be an early reformer toward the relaxation of visa policy requirements as a strategic move in boosting its tourism sector (ADB, 2016) and as a consequence, the country has registered $7 \%$ annual growth in international tourism arrivals between 2009 and 2014 (African Economic Outlook, 2014). Seychelles is the only SADC country that features in the top 10 economies worldwide that prioritise travel and tourism the most (World Economic Forum, 2015). The Gross Domestic Product of Seychelles was US\$1.423 billion in 2014 (World Bank, 2015) and it has since moved from being an Upper Middle Income Country to a High Income country according to the World Bank's 2015 classification (World Bank, 2015). The economic consequences of visa restrictions are quite broad and far-reaching particularly on the tourism and hospitality sector. The African Development Bank (2013) notes that, prior to 2013, Mauritius required all its visitors to apply for visas before arriving, while Seychelles does not require entry visas at all, and this has contributed towards high tourist growth.

\section{Promotion of cost savings through visa facilitation}

$\mathrm{Hu}$ (2013) contends that, the use of visa waivers contributes significantly towards cost savings for implicated destinations or countries. However, the situation gets different especially in circumstances where existing visa policies are largely based in issues of reciprocity and are therefore in a constant flux of international relationship policies between the concerned countries. Literature available on this discourse suggests that, e-visa systems tends to aid governments towards the minimisation of rejection rates, border integrity maintenance, and the decentralisation of responsibilities that usually strain entry border resources (Rizzi, 2014).

\section{Deterring legitimate visitors}

It is imperative to note that legitimate tourists and other visitors are bound to be deterred from leisure travel as a result of the cumbersome and overly restrictive visa requirements. Existing research on this has found out that there is a symbiotic relationship between the value that the visitor places on their time and budget. It is in this perspective that, obstructive visa requirements for 
certain passport holders may be the cause of both opportunity costs and negative traveller perceptions to countries that may otherwise benefit from the tourism revenue. It would seem that trade; foreign direct investment (FDI), foreign business interests and tourism are economically desirable. The question that arises and probably requires future research in the context of SADC is why do SADC member states continue to impose stringent visa restrictions if this serves to hinder their economic potential? Additionally, why do SADC member states continue to use largely paper based visa systems?

An interesting case within the context of the SADC region that was greatly affected by the change in terms of its visa and immigration policies is South Africa. In 2014, South Africa launched its new visa requirements, where anyone travelling with a minor under the age of 18 - either to or from South Africa - was required to present an unabridged birth certificate at the port of entry in South Africa, in addition to a normal passport and visa. The visa regulations were mainly geared towards countering human and child trafficking and improving border control and security.

In light to all this, visa requirements serve to pre-select visitors, compile visitor demographic and deter the so-called undesirables. Interestingly, the literature available on this discourse shows that autocratic regimes actually use stricter visa requirements as a way of deterring foreign influences that may undermine the controlling regime all in the name of safeguarding territorial integrity. On one hand, the developing countries and those whose economies are anchored on tourism revenues, however, pose fewer visa restrictions. On the other hand, major tourism destinations also wish to stay competitive in the ever-increasing market of available mass tourism destinations such as the Bahamas, the Cayman Islands and Maldives. However, the problems that are inherent in outdated visa application processes include the deterrent of legitimate travellers, but also the overhead costs to the governments as they invest in labour and material necessary to staff and organise these outdated procedures. 


\section{Conclusions and Implications of the Paper}

Visa restrictions have broad economic consequences, notably for the tourism sector. Prior to 2013, Mauritius required visitors to apply for visas before arriving, while Seychelles does not require entry visas at all - this has led to a high gap in tourist growth. The number of tourists to Seychelles has grown by 7 per cent per annum in the last five years while Mauritius has remained almost stagnant. As a result, the Mauritian Government are trying to boost tourism by relaxing visa regimes for 30 African countries and 75 countries overall. The SADC sub-region can benefit from tapping into global trends on facilitating freer movement of people by devising strategic visa openness solutions and this will also go a long way in reaching milestones that are set out in the African Union's Agenda 2063 that includes key among them the removal of restrictive visa requirements across the continent by the year 2018 and the creation of the African passport. This paper also notes with concern that, visa reciprocity in SADC in general and Africa in particular remains very weak (McKinsey \& Company, 2015). There is no doubt as suggested by Douglas et al., (2012) that the SADC regions and its member states stand to gain from promoting visa free regional blocs and more should be done in terms of propagating the issue of visa reciprocity among member states and non- SADC member states.

Electronic visas or e-Visas can be a more effective alternative to traditional paper visas given that online visas do not require the traveller to be physically present or to present a passport before travel. However, a request for an eVisa does not automatically give the visitor the visa, which can be accepted or refused and costs paid may not be reimbursed. Beyond tourism, visa requirements imply missed economic opportunities for intra-regional trade, and the local service economy (such as cross-country medical services or education). Improving visa facilitation could generate an additional US $\$ 206$ billion for the tourism sector alone, and create as many as 5.1 million new jobs by 2015 in the G20 countries (WEF, 2013). Tourist arrivals to Africa will grow at double the pace compared to advanced-economy destinations and the SADC region will only benefit from this forecast by reducing visa barriers that currently 
makes the sub-region to be a closed off destination. The tourism industry represents three per cent of global employment, with indirect employment included it contributes to around one in every 11 jobs worldwide. The industry is expected to grow with a pace of 3.3 per cent per year.

The debate on visa openness is beginning to gain momentum and development economists are of the opinion that open borders could double the world GDP (Naik, 2013) thus bringing benefits to migrants in the form of higher income and opportunities. Additionally, host countries stands to benefit in terms of skills that are gained and jobs created as more workers need more managers. This counters the local fears of jobs being lost or a labour market being flooded. The purchasing power also rises with growing demand for more goods and services (Naik, 2013). If city states like Singapore and smaller states like UAE have management to address concerns around free movement of people and remain economically competitive and continue to attract foreign talent. It is recommended that SADC do the same.

The issue of immigration and free movement of people and visa openness for Africa continue to be on top of the agenda of so many high-level discussions, from the World Economic Forum Global Agenda Council on Africa to EU-Africa Leaders Valletta Summit on Migration in November 2015. Despite all these efforts, the visa policies that are in place in the SADC region continues to act as an inhibiting factor that facilitates orderly, safe and regular migration. The goal of this paper was to document the level at which the SADC sub region is being affected through its restrictive policies and the intention is now to shift the mindset from looking at the borders as barriers blocking out risks to viewing the borders as gateways that can usher SADC region into greater creativity and connectivity for tourism development, growth and competitiveness. Visa openness matters for SADC in order to capitalise on the continent's demographic dividend and encourage her dynamic, growing young population to seize opportunities to shape the regions a competitive strategic hub for tourism. Tourism in SADC can only be nurtured by allowing people to move with greater freedom. Outside this, the visa policies will remain an exclusion element that inhibits tourism growth. 


\section{References}

Africa Development Bank (2013). Visa restrictions and economic consequences in Africa http://www.afdb.org/en/blogs/afdbchampioning-inclusive-growth-across-africa/post/visa-restrictionsand-economic-consequences-in-africa-11987/ (Accessed 13 May, 2016) Africa Development Bank (2016) Africa Visa Openness Report 2016. Abidjan, Africa Development Bank http://www.afdb.org/ fileadmin/uploads/afdb/Documents/Generic-Documents/Africa _ Visa_Openness_Report_2016.pdf (Accessed 15 March, 2016)

African Economic Outlook (2014). Global value chains and Africa's Industrialisation. Abidjan: Africa Development Bank

Anholt, S. (2005). Anholt Nation Branding Index. How does the World See America? Journal of Advertising Research, 45(3), 296 - 304.

Anholt, S. (2002). Nation branding: a continuing theme. Journal of Brand Management, 10(1), 59-60.

Anholt, S. 2002. Foreword. Journal of Brand Management, 9(4/5), pp 229 239.

Ayikoru, M. (2015). Destination competitiveness challenges: A Ugandan perspective. Tourism Management, 50 (1), 142 - 158.

Balakrishnan, M.S. 2009. Strategic Branding of Destinations: A framework. European Journal of Marketing, 43(5/6), 611 -629.

Bianchi, R. (2006), "Tourism and the globalization of fear: analysing the politics of risk and (in)security in global travel", Tourism and Hospitality Research, Vol. 7 No. 1, pp. 64-74.

Buhalis, D., \& Law, R., 2008. Progress in information technology and tourism management. 20 Years on and 10 Years after the Internet - the state of eTourism research. Tourism Management, 29, 609 -623.

Douglas, A., Lubbe, B.A \& Kruger, E.A (2012) Would a single regional visa encourage tourist arrivals in southern Africa? Development Southern Africa, 29(3), 488 - 505

Du Plessis, E., Saayman, M., \& van de Merwe, A., (2015). What makes South African Tourism competitive? African Journal of Hospitality, Tourism and Leisure, 4(2), 1-14

Dwyer, L., Edwards, D., Mistilis, N., Roman, C., \& Scott, N. (2009). Destination and enterprise management for a tourism future. Tourism Management, 30, 63 - 74 .

European Commission Directorate-General Home Affairs (2011), “Overview of Schengen Visa Statistics 2009-2011". Directorate B: Immigration and Asylum Unit B.3: Visa Policy, available at: http://ec.europa.eu/dgs/home-affairs/what-we-do/ policies/ borders-andvisas/visa-policy/ docs/ overview _of_schengen _ visa _ statistics_2011_final_en.pdf (accessed 16 May 2016). 
Glaesser, D \& Kester, J. (2013) Visa Facilitation: Stimulating Economic Growth and Development through Tourism, World Economic Forum, Geneva.

Hays, S., Page, S.J., \& Buhalis, D. 2013. Social media as a destination marketing tool: its use by national tourism organisations. Current Issues in Tourism, 16(3), 211 - 239.

http:/ / traveller24.news24.com/TravelPlanning/VisaInfo/INFOGRAPHI

C-Impact-of-SAs-new-visa-rules-on-tourism-20151001 (Accessed 19 August, 2016)

$\mathrm{Hu}, \quad$ X. (2013), "Economic benefits associated with the visa waiver program: a difference-indifference approach", Global Journal of Business Research, Vol. 7 No. 1, pp. 81-89.

Kotler, P. \& Gertner, D. 2002. Country as a Brand, Product, and Beyond: A place of Marketing and Brand Management Perspective. Journal of Brand Management, 9(4/5), 249.

Lieberman, J. and Lautenberg, F. (1991), "Passports have become political symbols", Telegram \& Gazette, Vol. 28, pp. 55-57.

Lieberman, J. and Lautenberg, F. (1991), "Passports have become political symbols", Telegram \& Gazette, Vol. 28, pp. 55-57.

McKinsey \& Company (2015), “Unlocking Africa: Simplifying visas to allow the free flow of talent"

McKinsey \& Company 2015, “Unlocking Africa: Simplifying visas to allow the free flow of talent"

Molina, M.A. R., Frías-Jamilena, D. M., \& Castaneda-García, J. A. (2013). The moderating role of past experience in the formation of a tourist destination's image and in tourists' behavioural intentions. Current Issues in Tourism, 16(2), 107-127.

Naik, V (2013)If People Could Immigrate Anywhere, Would Poverty Be Eliminated? Some economists are pushing for "open borders" http://www.theatlantic.com/international/archive/2013/04/ifpeopl e-could-immigrate-anywhere-would-poverty-be-eliminated/ 275332/ (Accessed 25 July, 2016)

Neumayer, E. (2006). Unequal access to foreign spaces: how states use visa restrictions to regulate mobility in a globalised world. Transactions of the British Institute of Geographers, 31(1), 72- 84.

Neumayer, E. (2010), "Visa restrictions and bilateral travel", The Professional Geographer, Vol. 62 No. 2, pp. 1-25.

Pestana, B.C., Laurent, B., Nicolas, P., Elisabeth, R., Bernardin, S. \& Assaf, A.G. (2011). Performance of French destinations: Tourism perspectives. Tourism Management, 32, 141 - 146.

Rizzi, M.D. (2014) "Travel visa impacts on destination choice and perception", Worldwide Hospitality and Tourism Themes, Vol. 6 Iss: 4, pp.305 - 316 
Song H, Dwyer L, Li G, Cao, Z. (2012). Tourism Economics Research: A Review and Assessment. Annals of Tourism Research, 39 (3), 1653-1682.

Song, H., Gartner, W.C \& Tasci, A.D.A (2012), Visa restrictions and their adverse economic and marketing implications - Evidence from China. Tourism Management, 33, 379 -412.

Torpey, J. (1998). Coming and going: on the state monopolization of the legitimate 'means of movement'. Sociological Theory, 16, 239-259.

Travelle24 (2015). Infographic: Impact of SA's new visa rules on tourism. http://traveller24.news24.com/TravelPlanning/VisaInfo/INFOGRA PHIC-Impact-of-SAs-new-visa-rules-on-tourism-20151001 (Accessed 12 November, 2015)

Traveller 24 (2015) INFOGRAPHIC: Impact of SA's new visa rules on tourism

United Nations Conference on International Travel and Tourism (1964), Recommendations on International Travel and Tourism, August 21September 5, 1963. Rome.

UNWTO (2015) Visa Openness Report 2015. Madrid. United National World Tourism Organisation.

UNWTO (2016). Visa Openness Report 2016. Madrid. World Tourism Organisation

UNWTO. (2003). "World Tourism in 2002: Better than Expected" Vol, 2003: UNWTO, Madrid.

UNWTO. 2013. World Tourism barometer - tourism trends and marketing. Madrid.

UNWTO. 2015. Over 1 billion tourists travelled abroad in 2014" Tourism Highlights 2014 Edition, Page 2. http://media.unwto.org/pressrelease/2015-01-27/over-11-billion-tourists-travelled-abroad-2014 (Accessed, 15 March, 2015).

Viviers, P. \& Slabbert, E. 2012. Towards an instrument measuring community perceptions of the impact of festivals. Journal of Human Ecology, 40(3), 197 -212

Webster, C \& Ivanov, S (2015). Geopolitical drivers of future tourist flows", Journal of Tourism Futures, 1(1), pp.58 - 68

Whyte, B.R. (2009) Visa free travel: An Indicator of Global Integration. Monitoring and Measuring Regional Integration: EDB Eurasian Integration Yearbook

World Bank (2015). New country classifications by income level. http://blogs.worldbank.org/opendata/category/tags/news (Accessed 10 Jun 2016).

World Economic Forum (2015). The Travel and Tourism Competitiveness report 2015: Growth through Shocks. Geneva: World Economic Forum. 
World Tourism \& Travel Council (2012), "Travel and Tourism 2011". News \& Media, available at: www.wttc.org/ site_media/ uploads/ downloads/traveltourism2011.pdf (accessed 15 March 2016).

World Tourism Organization (2011), Tourism Towards 2030: Global Overview, UNWTO, Madrid.

World Travel and Tourism Council (2013). Travel and Tourism Competitiveness Report 2013. Geneva. World Economic Forum.

WTTC (2014) Travel \& Tourism Economic Impact 2014 World. Geneva. World Travel and Tourism Council.

WTTC (2015) Travel \& Tourism Economic Impact 2015 World. Geneva. World Travel and Tourism Council 